Portland State University

PDXScholar

\title{
Breaking the Feedback Loop: Experimental Filmmakers Confronting Everyday Surveillance Technologies
}

Taz Coffey

Portland State University

Follow this and additional works at: https://pdxscholar.library.pdx.edu/honorstheses

Part of the Contemporary Art Commons, Other Film and Media Studies Commons, Theory and Criticism Commons, and the Visual Studies Commons

Let us know how access to this document benefits you.

\section{Recommended Citation}

Coffey, Taz, "Breaking the Feedback Loop: Experimental Filmmakers Confronting Everyday Surveillance Technologies" (2021). University Honors Theses. Paper 973.

https://doi.org/10.15760/honors.997

This Thesis is brought to you for free and open access. It has been accepted for inclusion in University Honors Theses by an authorized administrator of PDXScholar. Please contact us if we can make this document more accessible: pdxscholar@pdx.edu. 
Breaking the Feedback Loop: Experimental Filmmakers Confronting Everyday Surveillance Technologies

\author{
by \\ Taz Coffey
}

\begin{abstract}
An undergraduate honors thesis submitted in partial fulfillment of the requirements for the degree of

Bachelor of Arts/Science

in

University Honors

and

English/Film Studies
\end{abstract}

Thesis Advisor

Dr. Kristin Hole

Portland State University 


\section{Breaking the Feedback Loop: Experimental Filmmakers Confronting Everyday Surveillance Technologies}

"But you too might get trapped in your own singular hell of a future repeating invented pasts, with one part of the population hell-bent on getting rid of another. People will peer in from afar, conclude they can't understand what's going on, and keep watching cat videos" --Hito Steyerl, Duty Free Art (57)

\section{Surveillance Art}

"Surveillance Art" is something of an enigmatic, umbrella term for art that deals with questions of surveillance and control, appropriating surveillance technologies and turning them into art objects, or even surveilling its audience. This ambiguous art practice stretches across disciplines, from 2D photographs of surveillance cameras, to interactive drone video art, as seen in Alex Rivera's “Low Drone” (2005), ${ }^{1}$ to short experimental films, to which I pay particular attention in this paper. Because some of these works come off as one-dimensional, observational critiques, as in photographs of CCTV cameras or self-surveillance livestreams, ${ }^{2}$ art about surveillance is often seen as cliched and overdone. Much of mainstream surveillance art, and therefore popular understandings of surveillance, are concerned with what surveillance looks like. In this essay, I explore three video works that could be lumped into the reductive monolith that is surveillance art, and yet they work against the grain of surveillance in the popular imaginary by focusing on what surveillance does, i.e. what are its affects--does it restrict mobility, induce fear, etc.--and the ways in which it's interconnected with our media and everyday life. I discuss The Giverny Document (2019), by Ja'Tovia Gary, who is a

\footnotetext{
${ }^{1}$ Rivera, Alex. "LOWDRONE: USA/Mexico, 2005, Website \& Installation.” 2005, alexrivera.com/project/lowdrone-installation.

${ }^{2}$ See for example, "WATCHED!" Hasselblad Foundation, 2016, www.hasselbladfoundation.org/wp/portfolio_page/watched-2.
} 
Brooklyn-based video artist working with handmade film and archival materials to critique the everyday surveillance of blackness. I then move onto Home Movies Gaza (2013), by Basma Alsharif--a Palestinian, French and American filmmaker who bases this particular work in the Gaza strip and abstracts military and media surveillance technologies to make tangible the violence of Israeli occupation. The final section ties Hito Steyerl's satirical tutorial on evading surveillance, How Not to be Seen: A Fucking Didactic MOV File (2013), which higlights the paradox of resisting visibility through visibility politics.

In terms of how surveillance, and more specifically surveillance art, is popularly understood, I'd like to briefly extrapolate on two better-know projects as examples of what I'm talking about: Ai Weiwei's 2015 CCTV Camera sculpture, Surveillance Camera and Plinth (Fig. 1), ${ }^{3}$ and Bruce Nauman's 1969 interactive Video Surveillance Piece: Public Room, Private Room (Fig. 2). ${ }^{4}$ Ai's piece monumentalizes a CCTV camera by carving its shape into marble and thus invoking the ongoing history of surveillance, relationships between surveillance and nationalism, and the omnipresence of surveillance cameras today. The piece attempts to induce paranoia through its towering and obvious presence, and reminds the audience of their perpetual status as subjects under state surveillance. Private Room, Public Room comprises two rooms (one labeled private and the other public), several monitors, and a few security cameras. It is described thusly: "In one corner" of the "public" room, "there is a monitor placed at floor level. It screens a camera pan of the room. Positioned on the ceiling, a camera diagonally opposite films the situation. When attempting to see yourself on the monitor, you soon discover that you only appear via another monitor. You see yourself in a monitor which features another monitor image

\footnotetext{
${ }^{3}$ Weiwei, Ai. Surveillance Camera and Plinth. 2015, Mary Boone Gallery, New York.

${ }^{4}$ Nauman, Bruce. Video Surveillance Piece: Public Room, Private Room. 1969.
} 
- namely the movements in the room you are in." There is an adjoined room labeled "private" with a supposedly identical setup, allowing Nauman to blur the line between the public and private. Both of these projects are representative of two conventional and intersecting ways of understanding how surveillance operates today: one being that the camera epitomizes surveillance culture, and is mythologized as an omniscient, all-powerful object, thus perpetuating the idea that surveillance only operates visually and therefore panoptically, and the other being that in a heavily surveilled society, there is no "private"--surveillance seeps into all corners of an individual's life, producing docile and cooperative subjects. Nauman and Ai similarly focus on camera and subject as loci of surveillance in order to impose a hyper awareness of being watched reminiscent of the disciplinary subject outlined in Michel Foucault's Discipline and Punish. ${ }^{6}$

\section{From Discipline to Control}

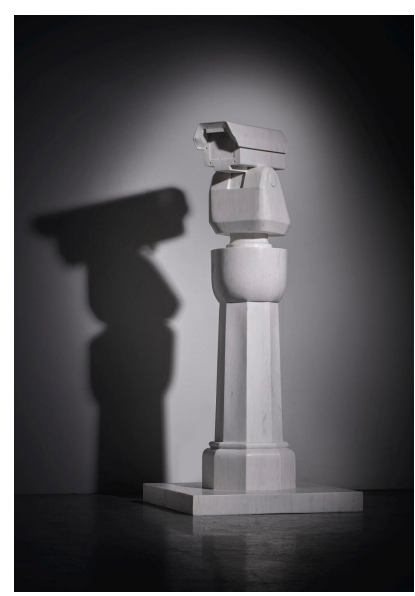

Figure 1

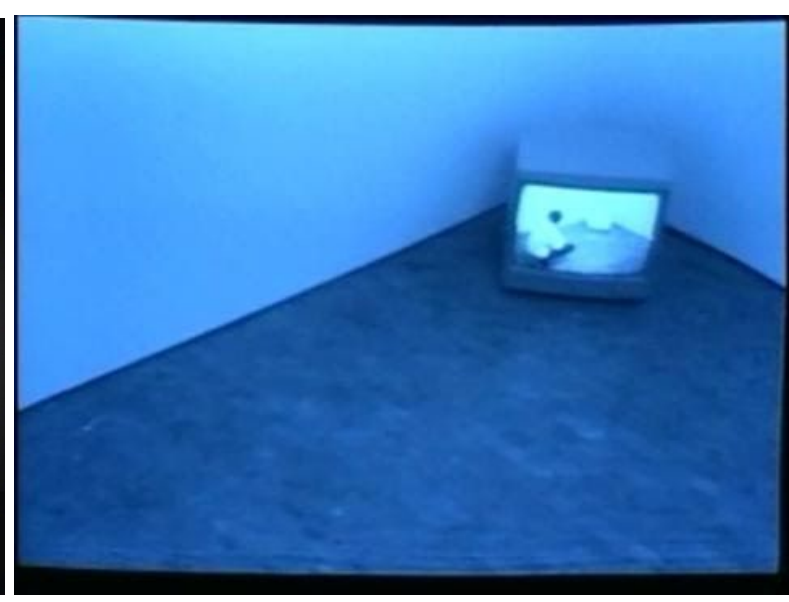

Figure 2

Nauman's boundary-pushing work of course preceded Discipline and Punish, which Foucault published in 1975. These two works, however, reflect a mode of theorizing modern power which was popularized around that time: societal subjects are disciplined not through displays of suffering and bodily pain as they were during pre-modernity (think public execution),

\footnotetext{
${ }^{5}$ Media Art Net. "Media Art Net: Nauman, Bruce: Video Surveillance Piece: Public Room, Private Room." Video Surveillance Piece: Public Room, Private Room, Media Art Net, www.medienkunstnetz.de/works/video-surveillance-piece/video/1/.

${ }^{6}$ Foucault, Michel. "Panopticism," Discipline and Punish. Random House, 1995, pp. 195-228.
} 
but through a self-disciplinary conditioning of the mind whose mechanism is replicated across social institutions--the school, the home, hospitals, military, prisons, etc. Foucault uses Jeremy Bentham's Panopticon prison model as a blueprint for how society disciplines subjects: in the center of a round building stands a guard tower out of which the theoretical "guard" can see into any cell on the perimeter of the building. Those inside of the cells cannot see into the guard tower, but they know that a guard could be watching them at any given time. Ultimately, a guard does not ever need to be in the tower to maintain the illusion of surveillance. This triggers a sort of self-disciplinary conditioning of the surveilled subject, wherein the prisoner, worker, student, patient, etc. conforms to the institution's code out of an internalized fear of getting caught.

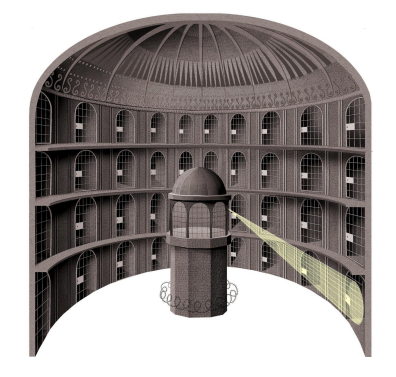

The Panopticon itself is an architectural invention that represents the "ideal" spatial arrangement of an institution. By reminding prisoners or subjects that they are perpetually under surveillance, the Panopticon has the effect of turning subjects into self-disciplining, self-regulating individuals, thus minimizing the inefficiency of a central spectacle of power and maximizing the "surface area" of people disciplined at one time. When Foucault claims that "visibility is a trap," he is referring to the fact that through the Panopticon model, the center of power is invisible while everyone else is subject to constant surveillance, observation, and examination. This allows for the mechanism of power to continuously produce knowledge of the subject, maximizing the productive effects of discipline. The Panopticon model is useful in thinking not only about how power and discipline might work in a prison, but also about how 
power relations function in everyday life--on all levels and in all institutions. The rise of disciplinary subjection and the rise of capitalism work hand in hand, which requires that technologies of discipline penetrate the everyday.

In his essay "Postscript on Control Societies," Gilles Deleuze (1992) explains that our late-capitalist world is moving away from disciplinary societies, which function primarily through confinement and restricting an individual's movement from one "closed site" to another, i.e. from school to workplace. ${ }^{7}$ As control societies take over, institutions dissolve and morph into one free-flowing, modulating, molding, and continuous technology of control. The factories, schools, and hospitals of disciplinary societies morph into corporations and businesses with meritocratic ideals. Control societies are not concerned with "the duality of mass and individual" but rather view populations as data and information, in part because late-capitalism sustains itself on sales and marketing more so than it depends on production and reproducing the disciplined 'good worker.' He provides real-life examples of how some of these institutions are shifting with technologies of control: prisoners are released on minor charges under the condition that they must be tagged and under constant surveillance (house arrest); young students learn business practices in schools; biotechnology takes on the role of a healthcare provider but only serves to profile the "healthiness" and contagion of populations. All the while, we're under the impression that these shifts mark progress toward a more free society.

I bring Foucault into conversation with Deleuze to illustrate how disciplinary regimes fade as the hard-working, obedient "individual" matters increasingly less in an age of mass data and information synthesis. One cannot discount how surveillance changes alongside this massive shift in how society is managed. For example, current surveillance technologies keep people in their "proper" places while adapting to new information produced by algorithms without

\footnotetext{
${ }^{7}$ Deleuze, Gilles. "Postscript on the Societies of Control." October, vol. 59, 1992, pp. 3-7.
} 
necessitating the presence, or even the illusion of presence, of disciplinary figures such as the prison guard or a manager. Nor do they care about the mythologized "individual" in our culture: connections and networks are more valuable, as in Facebook building "shadow profiles" of people who don't have Facebook accounts using information from their contacts. ${ }^{8}$ The panoptic layout of the factory is replaced by the ethos of the corporation, and production is replaced by the acquisition of information and data. Deleuze's theory aids in understanding how surveillance can no longer be theorized in disciplinary terms as an all-seeing, panoptic technology; as power changes, so must the technologies which extend it. Thus, in discussing surveillance art, I highlight work that interrupts our focus on the individual subject as the primary target of surveillance technologies. Similarly, we must shift our attention from visible forms of surveillance, such as the cctv camera or the TSA, to its less recognizable, everyday manifestations: data collection and analysis, (social) media, and as an economy of fear and paranoia.

\section{Problematizing the Visual Field}

Of particular focus in this paper is how media--particularly social media--intersects with surveillance practices and perpetuates an economy of fear and paranoia that then allows for popular consensus on the increase of surveillance and security practices. I write this paper in the wake of the summer of 2020--millions of people have taken anti-racist action and engaged in massive Black Lives Matter protests across the country (and world), with demands to defund the police and invest in the wellbeing of Black and brown communities. The video of police officer Derek Chauvin murdering George Floyd in many ways acted as a catalyst for current actions demanding the defunding and disbanding of police departments, among other demands such as

\footnotetext{
${ }^{8}$ Edelman, Gilad. “A Case Against the Peeping Tom Theory of Privacy.” Wired, Conde Nast, 15 Feb. 2021, www.wired.com/story/against-peeping-tom-theory-of-privacy/.
} 
closing prisons (though people have been doing this work for decades). I don't intend to discredit the power of such an infuriating and traumatic video to move some people toward direct action and away from whatever lies they were telling themselves about living in a country founded on genocide and slavery, and sustained by racial capitalism and state-sanctioned violence. But we've seen similar brutal videos reappear and disappear over the years: Rodney King, Eric Garner, Sandra Bland, Philando Castille, and countless other Black lives, some of which have also catalyzed action against the state. At the same time, it didn't take a video to spur the 2015 Baltimore protests nor the 2014 uprising in Ferguson. In his book concerning power in the information age, ${ }^{9}$ James Bridle argues that lack of international intervention into the Rwandan, Srebernican, and Kenyan genocides had more to do with an unwillingness of foreign powers to act than a "lack of information" and evidence, as they would claim in their defense. $\mathrm{He}$ challenges Google's CEO, who states, "If everyone had a smartphone," the Rwandan genocide would have been "impossible" because "somebody would have figured it out and...reacted to prevent this terrible carnage." ${ }^{10}$ According to Bridle, Google believes that "making something visible makes it better," and of course technology is the vehicle through which we render things visible. The weeks and days leading up to the Rwandan genocide were well documented, and the US even took classified satellite photos during the 100 days of genocide, but the UN and others withdrew support right before the crisis escalated. In Kenya in 2007, cell phones were the technology through which calls for violence and bloodshed circulated via text message, yet with no meaningful results in terms of international intervention. All of this is to say that we take for granted the apparent usefulness of surveillance technology and information--visual or otherwise--that "has been shown again and again to amplify violence and expose individuals to

\footnotetext{
${ }^{9}$ Bridle, James. New Dark Age: Technology and the End of the Future. Verso, 2019.

${ }^{10}$ Bridle, 242.
} 
its ravages." ${ }^{\prime 1}$ We have all of the video and photo evidence of atrocity that Google's CEO could ever dream of, but why aren't enough people, particularly those who profit off of and uphold white supremacy, as ready to act as they are to passively view systemic violence? Why isn't every single recorded instance of police brutality met with the same widespread outrage as was the video of George Floyd? Black Americans have been vocal about systemic oppression for centuries, so why are some people just waking up? I pose these questions to suggest that images and data documenting of atrocities such as police violence are not inherently conducive to affecting material change of any sort, and may in fact affirm the idea that things are getting better because they are visible.

Judith Butler theorizes that the act of "seeing" footage documenting racialized police brutality is not an objective act, ${ }^{12}$ but rather an act informed by the racist "episteme"--defined by Foucault as a set of relations in forms of thought and knowledge that characterize a period in time--that a Black (often male) body is always already performing violence within the "white racist imaginary." ${ }^{13}$ In her 1993 essay, "Endangered/Endangering: Schematic Racism and White Paranoia," Butler explains how before and during 1992's Rodney King trial, a highly publicized bystander's video capturing King being brutally beaten by LAPD circulated in the media and seemed to offer incontrovertible evidence that policemen had attacked an unarmed and defenseless man who showed no "visible resistance."14 Although this sort of documentation is ubiquitous in the 21st century, the video of officers beating King is one of the earliest of these "viral videos" to circulate in the mainstream. Somehow, the officers' defense, which relied on replaying the video in slow motion, managed to convince the disproportionately white jurors that

\footnotetext{
11 Bridle, 244.

${ }^{12}$ Butler, Judith. "Endangered/Endangering," Reading Rodney King, Reading Urban Uprising.

Routledge, 1993, pp. 15-22.

${ }^{13}$ Butler, 19.

${ }^{14}$ Butler, 15.
} 
this video only proved the unarmed King to be the source of danger against which the four officers had to defend themselves. The jurors read and interpreted the clips they saw against the grain of what was technically visible in the original video. Butler calls these diverging interpretations of supposed video "evidence" a "crisis in the certainty of what is visible: one that is produced by the saturation and schematization of that field with the inverted projections of white paranoia." 15 Through a "repeated and ritualistic" production of blackness as threatening within the white imagination and throughout history, seeing becomes an act of projecting paranoia--which originates in the viewer--onto the black victim, and then back onto the viewer who decides that shooting or beating is a justifiable act of self-defense. In short, racial ideology produces the way we see, and not the other way around. Butler proposes that we counter racist hegemony over the visual field with "aggressive readings" of "visual evidence" (i.e. footage of police brutality).

Butler is somewhat optimistic in suggesting that we can challenge a systemically racist visual realm by looking even harder at the spectacle of violence against Black individuals: a racist system informs the way we see, among other things, but reforming the way in which we see as individuals does not necessarily lead to a less racist system. The most obvious flaw with this proposal is that her own reading applies after the event (someone has already been injured), and is therefore not preventative. She implies that if officers took a moment to "read" the situation before beating or shooting, perhaps law enforcement could be anti-racist, too. What is missing in the assumption that "closer readings" of the spectacle of Black death and pain could challenge a white supremacist system is that society does not "misread" but rather necessitates Black death and containment, beginning with the enslavement of Africans and continuing today

\footnotetext{
${ }^{15}$ Butler, 16.
} 
with mass incarceration, police brutality, gentrification, white nationalist mass shootings, etc. ${ }^{16}$ While Butler in many ways echoes Bridle's beef with Google's hunger for increased visibility in stating "that [the officer's acquittal] was achieved not as the consequence of ignoring the video, but, rather, of reproducing the video within a racially saturated field of visibility," her interest still resides in reforming the field of visibility through the logic of visibility rather than exploring other forms of knowledge: Bridle wonders why people in power don't simply believe the oral accounts of marginalized groups in advance of tragedy, and then take corporeal or material action to support those being targeted within systems of oppression.

Jasbir Puar (2007) problematizes Butler's ocular logic in Terrorist Assemblages: Homonationalism in Queer Times, ${ }^{17}$ noting how "there is as well a reliance on the very act of seeing that Butler problematizes; while she is critical of the relationship between seeing and what then counts as visual evidence, she nonetheless centralizes the visible black body whose difference is seen and not felt, whose episteme cannot escape the chain of signs of danger qualified as the beginning, the end, the origin, intention, and object." ${ }^{\prime 18}$ In other words, Butler's focus on seeing alone perpetuates the illusion that contained within a sign or object are certain associations such as fear or a sense of danger. In this way, the individual subject is centered as a container of said affects with the implication that fear, in this case, begins and ends with encounters between individuals--the cop sees Rodney King, fear arises, he then projects fear onto King and squashes this fear by brutally beating him.

Focusing on what is felt, to augment our understanding of what is seen, allows us to conceptualize fear, or the anticipation of "threat," as part of an affective economy rather than an individual response/reaction to a sign or object. In his essay on the political ontology of threat,

\footnotetext{
${ }^{16}$ See Angela Davis, Ruth Wilson-Gilmore, Michelle Alexander (author of The New Jim Crow)

${ }^{17}$ Puar, Jasbir. Terrorist Assemblages: Homonationalism in Queer Times. Duke UP, 2007.

${ }^{18}$ Puar, 184.
} 
Brian Massumi (2010) reveals that preemptive action against threat dominates our logic, regardless of whether or not the threat is based in truth, "The felt reality of threat legitimates preemptive action...Any action taken to preempt a threat from emerging into a clear and present danger is legitimated by the affective fact of fear, actual facts aside." ${ }^{19}$ For the Bush administration, invading Iraq was right because, although there turned out to be no stockpiles of atomic weapons to use against the US, Saddam "would have [stockpiled weapons of mass destruction] if he could have. ${ }^{.20}$ Although this threat had no basis in proven fact, its past is felt as real looking back from the future and vice versa, and this purported threat had real, material consequences. As such, threat is nonlinear - a future threat retroactively asserts that there has always been a threat, and that its preemption does not foreclose the possibility for that threat to seep out and occur elsewhere: "If we feel a threat, such that there was a threat, then there always will have been a threat." ${ }^{21}$ Fear, then, is the "felt reality" or "affective fact" of anticipating (nonexistent) future threat, which, after the fact, is remembered as having been a real danger that was thankfully preempted.

Puar, referencing Sara Ahmed, suggests that fear as a tool of racist hegemony secures power through its nonresidence, or the inability of fear to be contained within an object. In "The Affective Politics of Fear," Ahmed, like Massumi, argues that contrary to most of its definitions, fear is not simply an emotional response to an objective threat. ${ }^{22}$ A perceived threat itself relies on the construction of an object or event as threatening through repeated instances of fear sliding between bodies and sticking to said object. Put simply, for every encounter that ends in a confrontation or containment of that fear, there are surely more brief instances in which fear

\footnotetext{
${ }^{19}$ Massumi, Brian. "The Future Birth of the Affective Fact," The Affect Theory Reader, 2010, pp. 52-67; 54, emphasis mine.

${ }^{20}$ Massumi, 55.

${ }^{21}$ Massumi, 54

${ }^{22}$ Ahmed, Sara. "The Affective Politics of Fear," The Cultural Politics of Emotion. Edinburgh UP, 2004, pp. 62-81.
} 
passes by and reproduces, or "sticks." This sticking, too, depends upon repeating stereotypes which already exist, but each encounter "generates a distinct category of the fearsome in the present. ${ }^{, 23}$ Stereotypes must be repeated at every encounter, meaning that every encounter is potentially unstable: "the very repetition that is required to enable such a fixation [of stereotypes] renders them a site of insecurity" because fear does not reside in a particular object or sign. ${ }^{24}$

It is fear's failure to reside which intensifies one's fear of the uncontainable "other" and paradoxically justifies expanding powers of detention and other modes of containment. That the unknown object of fear might "pass by" and postpone the threat it poses to life itself makes its uncontainability all the more fearsome. In discussing post-9/11 fear, Ahmed illustrates how this event-turned-fetish-object produces a nation of 'alert' citizens who turn fear--seen as the weapon of terrorists--into a declaration of war. The population "overcomes" fear and instead channels its energy into preserving life, namely by containing the potential object of fear before another deadly encounter is allowed to take place. Fear then sticks to bodies--those who appear or act Muslim, Arab, or Middle-Eastern--that are "read as associated with terrorism" insofar as fear does not reside and the terrorist could be anyone. The imagined terroristic actions of those who resemble terrorists are preempted through containment and restricted mobility. Key here is that while the intention is to contain objects of fear (anyone who seems like a terrorist), we end up with what Puar labels a "defended position," a position which those channeling their energy into patriotically preserving life enact by "preempting altogether the conditions of possibility" for an attack. ${ }^{25}$ Meaning, for example, the implementation of a stricter TSA specifically trained to pull aside people who seem on edge, who seem like they could be up to something, a hunch which is of course contextualized by various intersecting factors--a person's skin color, perceived gender,

\footnotetext{
${ }^{23}$ Ahmed, 75.

${ }^{24}$ Ahmed, 64.

${ }^{25}$ Puar, 185 , emphasis in original.
} 
the language they are speaking, an accent, their clothes, apparent mental illness, or perhaps their nervousness which may itself result from feeling "the fear they create." ${ }^{26}$ The more steps that are taken to identify and preempt the conditions of possibility for an anticipated attack, the more that fear sticks to bodies and is reproduced. This fear of potential terrorism can of course be transposed to fear of potential criminality, a threat that in the late 20th century circulated around calls for "Law and Order," leading to the rise of mass incarceration. ${ }^{27}$

This economy of fear expands and justifies surveillance, specifically racial profiling, and the indefinite detention of 'could-be' terrorists and criminals. Puar deepens this hole in the logic of ocular resistance by introducing "misrecognition" as a common framework as well as a key obstacle to complicating racist hegemony. In her chapter "The Turban is not a Hat," Puar begins by problematizing "mistaken identity" or "misrecognition" as a framework through which, to give one example, Sikh activists have addressed hate crimes directed specifically at turbaned men and women upon whom hostility is wrongfully displaced from the supposedly rightful target, the turbaned Muslim man. After 9/11, Sikh organizations launched a campaign that aimed to correct the ignorance of non-Sikh Americans by mapping out the visible identifiers of Sikh turbans and their cultural significance. The idea was that hate crimes against Sikhs would end if one could recognize a person as Sikh rather than Muslim. Yet, hate crimes against Sikhs, and certainly against Muslims, did not decrease in accordance with the campaign. This tactic privileges the visible or the "specular" as "an activity that can be easily disrupted in order to redress misrecognition and rearrange configurations of gender, sexuality, and race" and suggests that there is a rightful target of this fear and misplaced hostility, thus perpetuating and

\footnotetext{
26 Puar, 178.

${ }^{27}$ For example, Ofer, Udi. "How the 1994 Crime Bill Fed the Mass Incarceration Crisis.” ACLU, American Civil Liberties Union, 4 June 2019, www.aclu.org/blog/smart-justice/mass-incarceration/how-1994-crime-bill-fed-mass-incarceration-crisis.
} 
naturalizing the fear and paranoia that sticks to bodies perceived as potential terrorists. ${ }^{28}$ Puar points out that both Butler and Ahmed prioritize acts of reading as potential openings for resistance. For Butler, this looks like her own aggressive reading of the Rodney King trial; for Ahmed, it's those ritualistically repeated stereotypes that nevertheless are sites of insecurity to be taken advantage of.

The issue, again, is in theorizing the racial profile as a "misrecognition" that is more correctly a "resemblance," "a broader affective frame where the reason for the alikeness may be vague or repressed: from 'looks like' to 'seems like.",29 The "shadow profile," a la Facebook, works as a prime example for this distinction. You're not singled out by surveillance technologies for who you are as an individual. Instead, you're lumped into a group of people with similar data--the places they go, what they look like, the things they like, the things they buy, etc. Even if you're "off the grid," you'll still be bound up in a network of resemblance, or a shadow profile. This shift reflects back to Deleuze's control society and its ability to contain while simultaneously endowing a population with more "freedoms," which is certainly easier when you don't have to account for every individual to profit off of them. This form of control of course has more severe implications for Black and brown individuals in that their "resemblance," according to a white supremacist system, to terrorists and criminals, can cost lives. In speaking of resemblance as an affective frame, Puar proposes not that we leave behind the visual and signifying, but rather that we understand these knowledges through the realm of affect and tactile knowledge to excavate the processes and forces which either get mistaken for, contained or erased by the specular and the discursive. It is also important to examine what technologies hide behind these instances of passing through affective economies because "the ocular, affective, and

\footnotetext{
${ }^{28}$ Puar, 170

${ }^{29}$ Puar, 187.
} 
informational" are all mechanisms through which control is dispersed, and we cannot isolate them from one another.

How does all of this play into the three video works I discuss in the next section? Although not directly, all three artists address surveillance in its contemporary, everyday manifestations in such a manner that acknowledges a shift from surveillance technologies disciplining individual subjects to controlling populations through the logic of resemblance. More specifically, they elucidate the racist implications of this system: Basma Alsharif's experimental 24-minute film Home Movies Gaza (2013) deals with the Israeli state’s hyper-surveillance of Gazans, media spectacles of suffering, and other occupational technologies of control used against Palestinians. In How Not to Be Seen: A Fucking Didactic Educational .MOV File (2013), video artist Hito Steyerl satirically highlights paradoxes in the desire to be visible and the simultaneous need to become invisible at a time in which the image is inescapable, focusing on the trappings of being "undocumented or poor" within this system. With The Giverny Document (2019), Ja'Tovia Gary combines hand-processed film, various overlays, nature shots, as well as obscured footage from a video of police shooting Philando Castile to interrupt the viewer's surveillance of a brutalized Black man. In the next section, I discuss how each film contributes to interrupting a visually overdetermined feedback loop between surveillance and fear, paying particular attention to the unique ways in which each work accomplishes this.

\section{The Giverny Document}

Ja’Tovia Gary's The Giverny Document (2019) is a 42-minute audio-visual collage comprised of archival footage representing important moments and figures throughout Black 
history, complemented and interrupted by strips of hand-made, camera-less film, and juxtaposing segments in which Gary embodies various personas in front of the camera. ${ }^{30}$ In the first of these segments, Gary asks Black women and girls on the streets of Harlem, "Do you feel safe?"--a question about surveillance and security posed to an historically underprotected population (Fig. 3). Later in the film, Gary appears in Monet's Giverny garden, physically distanced from the everyday traumas of encountering white supremacy in America, while footage of the 2016 police murder of Philando Castile, filmed by Diamond Reynolds, disturbs a seemingly peaceful scene. In this segment, hand-made, cameraless film strips interrupt our expectation as viewers to see Castile's brutalized body, while Gary embodies the pain and fear of Reynolds through her performance in the garden. These segments come into conversation with archival clips of Nina Simone performing Morris Albert's "Feelings" (1975), in which she calls out the "conditions that produced a situation that demanded a song like that," perhaps reflecting Gary's position on her own creative practice. Archival images of Fred Hampton, who was one of many Black Panther Party members under constant surveillance--and eventually executed--by the government, are incorporated, alongside a seemingly dated educational film about Haitian independence, and drone strike footage. In this section, I explicate the connections Gary is making here between the everyday reproduction of Black trauma in visual culture and the past, present and future of anti-black surveillance and popular countersurveillance. I bring in Simone Browne's writing on the importance of understanding surveillance's embeddedness within histories of racial formation in order to interrupt the reproduction of the "racial schema" that justifies surveillance and violence directed at Black people, and her complication of countersurveillance, or "sousveillance" as inherently liberatory. ${ }^{31}$ The film refuses to replicate

\footnotetext{
${ }^{30}$ Gary, Ja'Tovia, director. The Giverny Document. 2019.

${ }^{31}$ Browne, Simone. Dark Matters: On the Surveillance of Blackness. Duke UP, 2015.
} 
spectacles and the surveillance of Black trauma and instead focuses on affective processes of working through daily violence and concerns for safety while also interrogating the conditions which allow for such traumatic content to surface, circulate, and ultimately fail to prevent future instances of police brutality, or make Gary feel any safer as a Black woman.

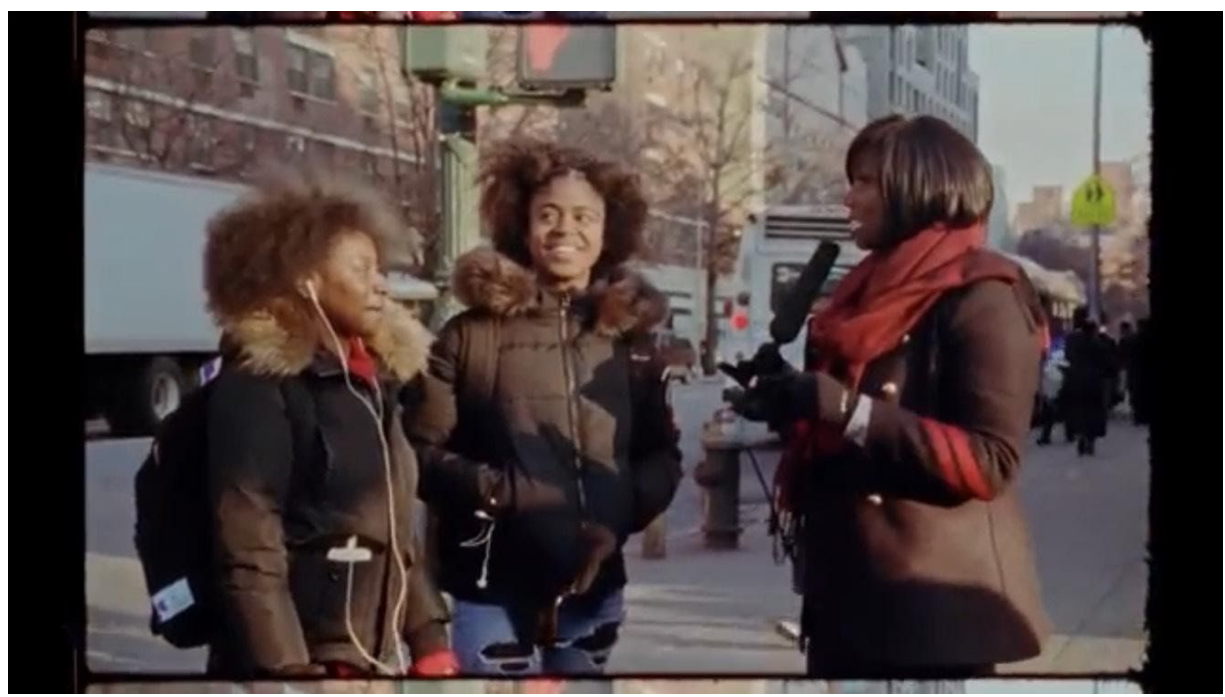

Figure 3

As Simone Browne puts it in Dark Matters: On the Surveillance of Blackness, surveillance "is the fact of anti-blackness." 32 Browne argues that behind contemporary technologies of surveillance in the U.S. and abroad hides a long history of racist violence that ranges from colonial surveillance and the branding of enslaved people as a precursor to biometric tagging and to policing and incarceration, all of which work(ed) to secure white domination and control over black and brown populations. Today, race structures surveillance practices and vice versa in much the same way as it has in the past, as creators of racially biased predictive facial recognition technologies invent algorithms which purport to measure the criminality of one's face, while police forces across the globe deploy racially biased facial recognition technology that, in one instance, sent the "wrong" Black man to jail. ${ }^{33}$ Of course, racialized surveillance

\footnotetext{
${ }^{32}$ Browne, 10.

${ }^{33}$ Hill, Kashmir. "Wrongfully Accused by an Algorithm." The New York Times, 24 June 2020, www.nytimes.com/2020/06/24/technology/facial-recognition-arrest.html.
} 
reaches beyond the empire of Silicon Valley and into everyday manifestations of oppression, such as increased police presence in low-income neighborhoods, stop-and-frisk practices, the criminalization of "Driving While Black," and the consumerist white gaze that has been extended through the media. ${ }^{34}$ This past and present of racial domination, Browne says, is accompanied by resistance to and survival under surveillance that ranges from stories of "camouflage" (enslaved people passing as white and facilitating the escape of others by posing as a master or overseer), to examples of "sousveillance"--the surveillance of those in power (e.g. the Police) by those typically under surveillance--such as Black Panther-organized neighborhood watches.

Browne argues that we can look to the archives for "moments of refusal and critique," but this archive must be "taken up in a way that does not replicate the racial schema that spawned it and that it reproduced, but at the same time does not erase its violence." 35 Awareness of these documents of oppression and resistance brings us a step closer to resisting and dismantling anti-black racism and the surveillance technologies which they inform, but cannot be seen as anti-racist in and of itself. This material must be interrupted in such a way that it does not reproduce its own conditions and instead critiques and refuses reproduction. Butler suggests that we aggressively unlearn the racist episteme informing acts of "seeing," and then take another look with critical eyes. But the ocular represents one facet of the archive--Browne pieces together a range of materials, from written correspondence, to slave ship and panopticon blueprints. As Puar suggests, the visual field is overdetermined as a locus of oppression and resistance. If we limit ourselves to reading and rereading what is visible, thus producing and reproducing knowledge around the same image that has been replicated over and over again

\footnotetext{
${ }^{34}$ Lafraniere, Sharon, and Andrew W. Lehren. "The Disproportionate Risks of Driving While Black." The New York Times, 24 Oct. 2015, www.nytimes.com/2015/10/25/us/racial-disparity-traffic-stops-driving-black.html.

${ }^{35}$ Browne, 13.
} 
throughout U.S. history (think Emmett Till as an earlier example), are we not replicating, or at the least overlooking, the "racial schema that spawned it?" Browne's method takes Butler's approach one step further, prescribing archival intervention as an interruptive and destructive material approach that reaches beyond readings of what is visible and centers the narratives that Black artists and historians reclaim.

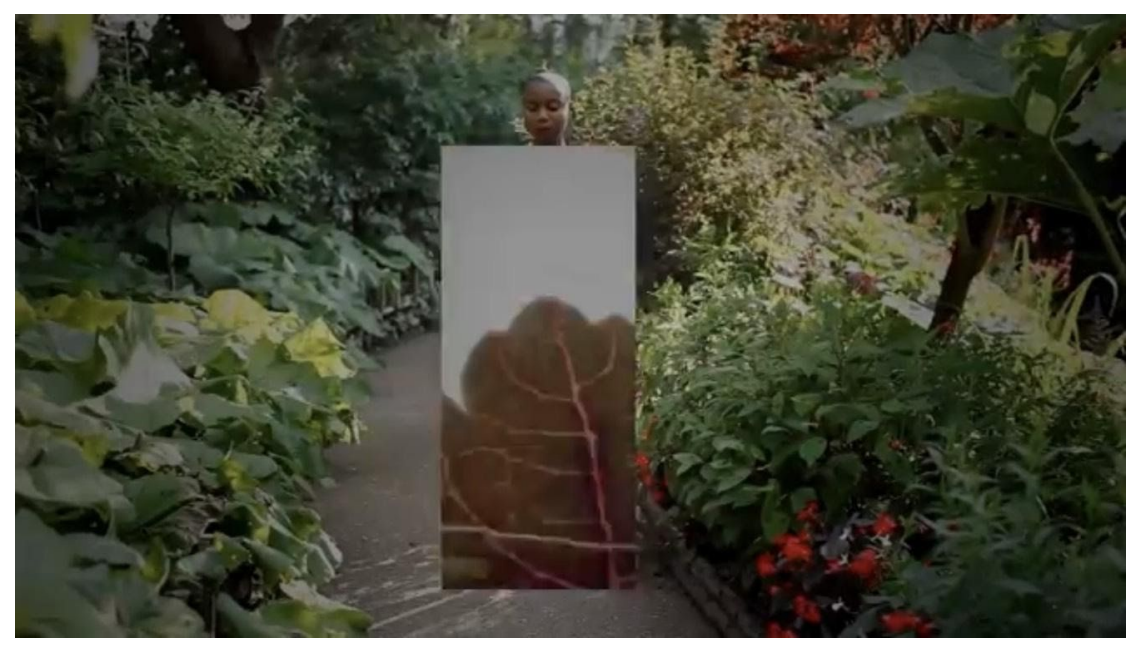

Figure 4

Gary's formal choices speak to the material manner in which she works through questions of trauma, safety and autonomy. Most notably, she digitally keys scans of handmade film onto the audiovisual narrative that she deconstructs and reconstructs, not only to blot out subjects and reconfigure the way in which we engage with these recorded events, but also to use her own body to interact with difficult material (Fig. 4). Throughout my analysis, I circle back to this technique as a critical form of archival intervention, which expands beyond the visual by representing an affective, embodied artistic process. Handmade film is a focal point for Gary's artistic practice, and it manifests differently in much of her work; in An Ecstatic Experience (2015) ${ }^{36}$ we watch geometric patterns, which Gary scratched directly onto the film, dance around actor Ruby Dee performing an excerpt of Fanny Moore's slave narrative. In Giverny, handmade film, composed of leaves affixed to a clear $16 \mathrm{~mm}$ film strip, is digitized and keyed

\footnotetext{
${ }^{36}$ Gary, Ja'Tovia, director. An Ecstatic Experience. 2015.
} 
onto the video, rather than featured as a stand-alone film. Regardless of the end product, the act of scratching into, or layering found objects on top of film carries implications unique to a cameraless process. For one, the artist touches and feels the physical objects which we later view as a two-dimensional moving image. Gary had to collect, smell, touch, and arrange each leaf, leaving noticeable traces of a time-consuming, tactile process even within the digital renderings.

The time it takes one to parse through and create such a visceral film object is of course disproportionate to the length of the film which we eventually screen. In Giverny, this difference perhaps represents a gap between her banal, everyday, tactile interaction with an affective economy that surrounds and informs the Castile event, and the documentation of one visual manifestation of this affective economy--the proverbial tip of the iceberg in contrast to all that lies beneath the surface. Harking back to Puar and Ahmed, fear, for example, functions as part of an affective economy rather than an individual reaction to a sign or object. Whatever fear or paranoia Castile and his murderer felt did not begin and end with those individuals--in preempting the conditions of possibility for an attack, Castile's killer took up Ahmed's “defended position," informed by an affective economy of fear in which racist paranoia sticks to uncontainable "others" that more often "pass by" than are confronted. ${ }^{37}$ Fear and anxiety circulate before and after the event, but are only perceived as an individual response particular to the event. In working with cameraless film, Gary enacts a process of interrogating her "uncontainability" and the threat that sticks to racialized bodies, eliciting her own feelings of fear, and working through those feelings using a repetitive, possibly meditative material process that is both personal and political. Time as it informs affect, and vice versa, is thus tied to understanding Gary’s multi-media, process-centered approach to issues of safety and autonomy. The crux of my discussion is that I stress the importance of archival interventions that stretch

\footnotetext{
${ }^{37}$ qtd in Puar, 185.
} 
beyond readings of what is visible, while simultaneously analyzing the work of a visual artist. I highlight the incorporation of hands-on media into the film as a whole to show that what appears to be solely visual disguises an entirely other process--as do the politics of affect. Handmade film plays a variety of roles in Giverny, but it's important to remember what it does in and of itself.

Early in the film, Gary repurposes the viral Facebook Live video of cops shooting Philando Castile to critically intervene in an archive of police brutality videos that are often taken for granted as inherently liberatory. The Negresse Imperiale segment of Giverny opens with a mix of nature-filled shots set in Monet's Giverny garden and the digital scans of handmade camera-less film. The editing is frantic, and whatever peacefulness one might expect from this natural atmosphere, accompanied by a soundtrack of the remixed song "La Vie en Rose," is warped by the implementation of dutch angles and brief shots of Gary in the garden, followed by footage of Fred Hampton. The Facebook Live video taken by Diamond Reynolds, Castile's girlfriend who was in the car with her daughter when he was shot, brings the music and montage to a halt. Philando Castile was a 32 year-old school nutrition aid who was pulled over for a traffic stop in the suburbs of Saint Paul, Minnesota. Police dashcam footage of the incident reveals that after Castile disclosed that he was legally carrying a firearm, Officer Yanez fatally shot Castile a total of seven times. ${ }^{38}$ The first documentation of the shooting, however, was filmed by Reynolds immediately after Yanez fired at Castile, and streamed live as events unfolded. ${ }^{39}$ Distress and trauma as experienced by the bystander are typically hidden, but here, they are laid out as Reynolds speaks to the camera, "My boyfriend just went like that." This

\footnotetext{
${ }^{38}$ Croft, Jay. "Philando Castile Shooting: Dashcam Video Shows Rapid Event." CNN, 21 June 2017, www.cnn.com/2017/06/20/us/philando-castile-shooting-dashcam/index.html.

${ }^{39}$ Al-hlou, Yousur. "Philando Castile, Diamond Reynolds and a Nightmare Caught on Video." The New York Times, 24 June 2017,

www.nytimes.com/video/us/100000005181340/philando-castile-diamond-reynolds-and-a-nightmare-caught-on-vide o.html.
} 
sudden interruption turns what may have once been a seemingly raw, objective viewing experience into an intense, heavily mediated shock for its audience.

The video is mediated further by Gary's choice to hide Castile's lifeless body behind a square of her handmade film scans. Superimposing an object over the lifeless and brutalized body of Castile decenters this hypervisible victim of police brutality and challenges our expectation to be able to scrutinize and produce knowledge on the subject, bringing attention to the highly mediated nature of documentary videos. In Butler's reading of the Rodney King tape, a disproportionately white jury projects their racialized fears onto King's body. Reproduction, both in the media and in the courtroom, of King's brutalized image surprisingly produced a spectrum of opinions about who exactly--King or the police--was a victim, despite the presence of what should appear to be an objective video depicting a group of police officers senselessly attacking King. I'd like to place emphasis on the idea, as Butler points out, that the video was "violently decontextualized" and recontextualized both in the courtroom and the media: "it is played without a simultaneous sound track which, had it existed, would have been littered with racial and sexual slurs against Rodney King." ${ }^{, 40}$ Indeed, the tape was often spoken over in news broadcasts and presented as soundless in the courtroom. Additionally, stills and close-ups of King's gestures were a focal point for the defense. The jury's focus, in the first place, was on King's body--what did he do, or not do, to deserve a fifteen-minute beating--rather than the officers' actions. The omission of sound appears to further direct focus away from the officers, as their targeted use of the n-word would contextualize the attack as racially motivated. In the news, Reynolds' original Facebook Live video--which begins right after Castile is shot--was fragmented and spoken over, although the full video remained available on Facebook. As in the first King trial, Castile's murderer, Officer Jeronimo Yanez, was acquitted of all charges, despite

\footnotetext{
${ }^{40}$ Butler, 20.
} 
video "evidence" of the bloody aftermath and a transcript that proved Castile's compliance. In this instance of documented police brutality, as was the case in the King trial, George Zimmerman's trial, and too many similar cases to count, people paid excess attention to what Castile did or did not do to warrant Yanez's deadly use of force. In hiding Castile's bloody and unresponsive body, Gary's film exposes both themes I've explored above: A) The video taken by Reynolds, or any video held up as objective countersurveillance, is mediated in and of itself, and toyed with further in the media--as demonstrated by Gary's overt manipulation of the raw footage; and, B) Through Castile's absence, we're forced to reconcile with the extent to which the ubiquitous image of the brutalized Black body is both a source of trauma and target for scrutinization.

The film's unwillingness to show Castile also establishes a direct relationship between the "citizen journalism" we see in the news/on social media and State surveillance. Castile's absence brings attention to the footage's creator, reorienting our fixation away from the brutalized body. In first capturing and then redirecting our focus, Gary complicates the role of bystander counter-surveillance--or "sousveillance"--as a romanticized and liberatory action. Sousveillance describes the act of watching the watchers--in a sense it works as countersurveillance, but with the implication that those "watching back" are under or beneath their watchers, hence the use of the French "sous" rather than "sur," which means on or over. One might argue that Butler's Rodney King video embodies a sousveillant gaze, but it can also be said that in this case the surveillant gaze multiplies as surveillance is conducted by a bystander in addition to the State. In other words, footage taken by a bystander may aid police in investigations and acts of profiling. ${ }^{41}$ And again, the Rodney King video was reproduced in court

\footnotetext{
${ }^{41}$ See, for example, Ring surveillance technology working with law enforcement: Harwell, Drew. "Doorbell-Camera Firm Ring Has Partnered with 400 Police Forces, Extending Surveillance Concerns." The Washington Post, 13 Dec. 2019 ,
} 
as evidence against King. The bystander, while intending to keep the state in check, also films the subject of violence who is already under surveillance. I expand upon this discussion about the bridge between documentary evidence and state surveillance further in the next section on Basma Alsharif's Home Movies Gaza.

We often watch these videos in a seemingly unmediated context that comes off as raw, objective counter-surveillance. We don't notice when the video starts and stops, or why (Did the bystander feel fear? Did the police seize their camera? Was it too traumatic to continue filming?). This bystander is often entirely absent from the frame. That Gary chose to work with Reynolds' video, in which the "bystander" talks directly at the camera, is telling of the piece's desire to move beyond a Butlerian "aggressive reading of the visible" while taking into account the fear and trauma that sticks not only to Castile's body, or the cop's body, but also to the bodies of those experiencing Castile's murder second-hand. A once raw, seamless video is exposed for all of the technological and emotional layers through which it passes. The film asks, what does it mean when the bystander is not a stranger but rather someone directly impacted by the event? The focus on Reynolds, combined with Gary's process-oriented handmade film, brings to light the shock and fear that is generated by the traumatic experience of watching a loved one die via state-sanctioned violence. As a "sousveiller," Reynolds is a proxy for those watching the video from elsewhere. Collective trauma and fear are brought to the surface through Reynold's and Gary's pain. This is amplified when we hear the cop yell “walk backward" as Gary's character walks backward in the garden, emulating Reynolds' experience, shown as having affective ripples beyond the killing of one man.

www.washingtonpost.com/technology/2019/08/28/doorbell-camera-firm-ring-has-partnered-with-police-forces-exte nding-surveillance-reach/. 
The film frequently circles back to a clip of Nina Simone's earth-shattering performance at the 1976 Montreux Jazz Festival, in which she riffs on Morris Albert's "Feelings":

For all my life I feel it, I wish I'd never seen it,

It can't possibly come again.

Feelings, whoa feelings, again in my heart/feelings of love.

As a hypervisible Black woman, Nina Simone is and was in many ways a symbol of Black Power, as she voiced her explicit and unflinching love of blackness. In the middle of the song, between speaking her mind and singing, she says, "Goddamn, what a shame to have to write a song like that," followed by, "I do not believe the conditions that produced a situation that demanded a song like that." Here, Gary gestures to a question that haunts the rest of Giverny: what kind of unbelievable conditions created the need for her to produce such urgent work? She makes a point to ground her work firmly in the conditions that propel her unique artistic process, in which she assumes full autonomy over her production as director, editor, actor, and everything in between. In a $B O M B$ Magazine interview, she recounts her experience as an actor encountering racial bias/gatekeeping in the theater world, while finding the film industry to be impenetrable. Thus, she sought to make work on her own terms. Similarly, Simone intended to become a classical pianist, but was denied admission to the Curtis Institute presumably on the basis of race, and wound up becoming one of the most formidable forces in music history. Gary's work is both a product of the conditions that barred a Black woman from taking a more mainstream route into certain institutions, and part of a process of autonomous self-making that in many ways resists the barriers she would encounter in a mainstream industry (not to say that those barriers are absent in the art world). As surveillance and anti-blackness are bound up in a 
politics of mobility, it's important to consider how the artist herself experiences and resists the limited mobility imposed by a white supremacist system.

\section{Home Movies Gaza}

With Home Movies Gaza, Basma Alsharif similarly shifts our attention from individual, sensational spectacle to affective representations of everyday violence under Israeli occupation. The 24-minute film opens with a handheld shot, played in reverse, taken from a car which wanders aimlessly around the Gaza strip, passing anonymous people and places. That the film opens with this shot, circulating but never seeming to arrive anywhere, sets us up for the rest of Home Movies, which evokes feelings of being stuck throughout. The film cuts to a heavily edited and layered scene, in which an anonymous woman who is made transparent through color keying recites a passage from Lord of the Flies, as her figure is layered atop shots of the ocean and harbor, followed by a series of scenes from within an unoccupied family home, where everyday domestic life is heard but not seen, and it is difficult to differentiate between diegetic and non-diegetic sound. When we do see domestic life, it is in the yard, where turkeys and chickens roam and eventually turn neon blue while a timer runs on screen to signal the use of military honing technology. Later, the camera captures a young woman playing cello, but the droning sound it creates is disjointed from the image. The film ends with someone scrambling through the dark wearing night vision goggles, as we see through their point of view, while sounds of drones and planes overwhelm the audio track. The visual and acoustic appropriation of night vision, honing technology, and drone sounds account for a few of the many ways in which Alsharif abstracts surveillance technologies employed by the Israeli military and places them 
within the context of a deadly everyday that both visualizes and makes audible the necropolitical violence of military and media surveillance in Gaza.

The Israeli State and its allies harness countless visual strategies to sanction the disappearance of Palestinians as both an assertion of dominance and control as well as a means to justify the official, doubtlessly violent, establishment of the Israeli State in the first place. For many Israelis, physical structures such as "eight-foot" walls and separate national roadways obscure any indication of Palestinian presence, effectively erasing signs of their existence. ${ }^{42}$ In "The Imperative to Witness and the Menace of the Global Gaze," Gil Z. Hochberg outlines how spectacles of both Palestinian suffering and violence in the media compliment this erasure to mask the continuous and unspectacular everyday violence that Palestinians face--this includes but is not limited to a lack of access to healthcare, clean drinking water, and the destruction of Palestinian crops and livestock. ${ }^{43}$ Meanwhile, military surveillance technologies such as drones, checkpoints, and human targeting devices render the occupied population hypervisible to the Israeli State, which increases their control over Palestinians. By abstracting these visual weapons, Home Movies Gaza interrogates this endless feedback loop of visibility/invisibility as a mode of occupying state power. Occupiers weaponize visibility through surveillance to establish complete control over the mobility and everyday life of Palestinians--surveillance technologies are ubiquitous in Palestine not only as an assertion of panoptic presence, but also as a means to collect information and to "know thy enemy." This is the logic of a "state of exception"--a manifestation of necropower wherein constructed states of terror and paranoia serve to justify indefinite violence toward a population under the guise of protecting people's autonomy against

\footnotetext{
${ }^{42}$ Hole, Kristin. "Negotiating the Aporias of Palestinian Identity through Experimental Moving Image Work" (Under Review).

${ }^{43}$ Hochberg, Gil. Z. "The Imperative to Witness and the Menace of the Global Gaze," Visual

Occupations: Violence and Visibility in a Conflict Zone. Duke UP, 2015, pp. 115-137.
} 
the enemy. In "Necropolitics," Achille Mbembé explains that necropower is a form of necropolitics, which means what it sounds like; it is a politics of death. ${ }^{44}$ As a concept, necropolitics builds on biopolitics by asking who gets the right to live and who, in turn, is placed in proximity to death. In diverging from biopolitics, Mbembé considers how the goal of contemporary politics itself is to kill: "Politics is therefore death that lives a human life." ${ }^{" 45} \mathrm{In}$ other words, sovereignty--the purported raison d'être of democratic politics--operates through the exclusion and annihilation of the "enemy." In his section "Necropower and Late Modern Colonial Occupation," Mbembe brings up the Israeli occupation in Palestine and apartheid in South Africa to show how necropower manifests in our contemporary moment. Both of these cases are, in different ways, examples of "the state of exception." We see this in Israel's unlawful expansion of settlements, but the same logic reminds us that Israel itself is a state of exception founded on the premise that Palestinian lives don't matter, and their existence is a threat to the legitimacy of Israel. As a technology of control, and one which also depends upon harnessing the fear and paranoia of non-Palestinians by painting Palestinians as security threats, surveillance upholds the state of exception in Gaza. Because Palestinians are perpetually hypervisible under the surveillant gaze, meaning their ability to practice autonomy and mobilize against their occupiers is limited, amplifying and collecting more visual information concerning Palestinians reproduces some of the same conditions that aid the state's necropower.

For Hochberg, rather than rendering invisible violence visible, Alsharif’s filmmaking refuses to provide "visual evidence of suffering" and posits "not that the world must be given the opportunity to see, but rather that the world spends too much time seeing." ${ }^{46}$ This recalls Bridle's sentiment that making something visible does not make it better, whether it be through the media

\footnotetext{
${ }^{44}$ Mbembé, Achille. "Necropolitics" Public Culture, vol. 15 no. 1, 2003, pp. 11-40.

${ }^{45}$ Mbembé, 15.

${ }^{46}$ Hochberg, 116,
} 
or a surveillance camera. In Home Movies Gaza, we're taken through sparsely peopled roads, living rooms, and the darkness of night. The landscape of Alsharif's film looks like a Palestine from which most of its people have disappeared, which of course interrupts the audience's expectation to see people, first and foremost, because this is a "home movie." In one drawn out scene, we find ourselves peering into someone's empty living and/or dining room--a relatively normal setting for a home movie, except that people are not on camera as perhaps they should be. Chatter and the clinking of silverware, and other signs of life, seep in from outside the frame, but their sources are never revealed. Hochberg problematizes "enormously saturated" and overdetermined visual depictions of Palestine and a global humanitarian reliance on rendering Palestinian suffering visible. It is in refusing to show what is already hypervisible that Hochberg finds potential for critique and resistance to "visual" occupation. While I agree with Hochberg's analysis, I would go so far as to say not that Alsharif refuses to show evidence of suffering, but rather that she illuminates the hidden everyday violence of surveillance by decentering the suffering of individual subjects and focusing on life itself, or the manifestations of bodies not as subjects but as sound and atmosphere. Here, Alsharif gives us signs of life via sound, shadows, and a room that is abandoned, yet seemingly livable, which makes the disappearance of subjects all the more powerful because we are left with the aura of their presence, signaling that people could appear in the shot, but our expectation is upended when the frame remains empty. Here, we're also confronted with an inversion of Gaza as seen through the media, where human suffering is highlighted against a backdrop of destruction. This presence of absence challenges media depictions of Palestine as a series of suffering faces and ruins while the physical location of home is overlooked. Here, there are no faces, ruins or spectacles of violence, only a room in which people may eventually appear, but not so long as the camera is turned on. 
The images and sounds Alsharif does put forward are as important as that which is absent--sounds of livelihood, such as people talking and eating, coexisting with sounds of occupation, such as drones and explosions. These sounds are accompanied by subjectless shots on location around Gaza. It is here that surveillance technology becomes the subject of Alsharif's film, challenging the way in which we think of military surveillance as a weapon of defense used to target dangerous individuals, and redirecting focus to surveillance as a tool which the state weaponizes to reproduce the conditions of fear that sustain it and render everyday life under occupation deadly. Coupled with the relative absence of human subjects, Alsharif imagines military surveillance's effect not on individuals but rather life itself. In other words, our attention is diverted from viewing Gazans as victims caught in the crossfire, so to speak, to understanding how rendering land, people, livestock, and all that sustains life as potential targets fuels Israel's expansion, and the expansion of control societies at large.

In another human-less "home movie scene," turkeys cluck around a backyard area. As in the living room scene, signs of life appear not through images of people but rather radiate out of objects and sounds which indicate human presence, thus inverting media tropes. The pastoral shot turns grim as animals in the scene become neon blue while a timer appears on screen, indicating that we're presently gazing through military targeting vision (Fig. 5). Everybody in Gaza, whether an uninvolved civilian or a resistance fighter, is a potential target. For Alsharif, even the livestock, by association, are targets. On one hand, her use of deadly surveillance technology on livestock and domestic animals symbolizes the everyday, slow violence performed by the Israeli State, including their limiting of clean water sources and burning of crops, causing food insecurity in the region, a necropolitical process which is not covered in the mainstream media. Simultaneously, the ubiquity of blue in the scene and the enclosed backyard 
environment is indicative of the limited mobility of Palestinians under surveillance. Through this double entendre, Alsharif reveals that a technology often understood as working on its own and with the specific purpose of targeting dangerous individuals is in fact part of a necropolitical system that marks all signs of life--so long as they represent a roadblock in the path to expansion--for death.

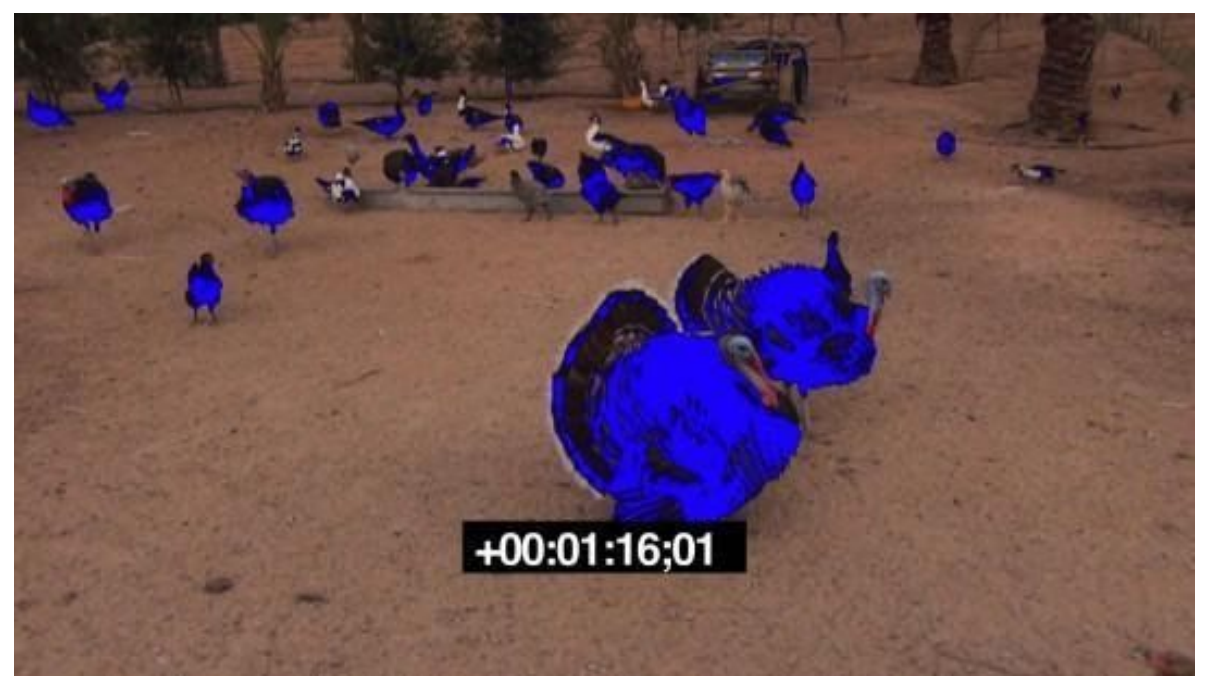

Figure 5

Returning to Puar's issue with "misrecognition" as a common but problematic framework for challenging the way in which visual power operates, critics of covert drone strike operations most notably in the Middle East performed by UAVs (Unmanned Aerial Vehicle) point to instances of drone "failure," in which civilian targets are taken out as the result of systematic flaws including "limits in drone video surveillance, signals interception, cultural understanding, and 'human intelligence' provided by local informants and cooperating governments." ${ }^{97}$ Critiques of targeting technologies revolve around revealing UAVs "tendency" to misrecognize targets due to a lack of the kind of technological intelligence and advancement in the field that proper targeting necessitates. Misrecognition reinforces the idea that there is a rightful object of

\footnotetext{
${ }^{47}$ Human Rights Clinic at Columbia Law School. "The Civilian Impact of Drones: Unexamined Costs, Unanswered Questions." Center for Civilians in Conflict, 2012, civiliansinconflict.org/publications/research/civilian-impact-drones-unexamined-costs-unanswered-questions/.
} 
fear, leading to preemptive action taken against the feared object. The application of this framework in interpreting civilian death as an accidental event of misrecognition fails to address the fact that Israel's expansion depends upon the death of Gaza as a whole. Perpetuating this logic allows those in power to avoid accountability for systemic and deliberate violence.

Thomas Stubblefield expands this outlook in Drone Art: The Everywhere War as Medium when he explains how "signature strikes"--in which "targets are identified according to a 'disposition matrix' of behaviors, locations, and personal relationships...often prompted by banal scenarios"--are becoming more common in covert military operations. ${ }^{48} \mathrm{He}$ details how in $2011 \mathrm{a}$ US military drone struck a non-war-related meeting between tribal Pakistani elders and killed forty-four people, pointing out that while governments frame these attacks as targeted killings, (and I would add that journalists and even critics of Israel frame them as "mistakes") US military-conducted drone strikes "are now based on these 'patterns of life' calculations rather than the identification of specific targets. ${ }^{{ }^{49}}$ As recently as November of 2019, one Israeli airstrike took out three unarmed civilians as they rode their motorbikes near Gaza City, while another aimed at two homes killed "two brothers, two women, and five boys aged 1, 2, 7, 12, and 13 , and injured a woman and nine other children"--all within twenty-four hours. ${ }^{50}$ The targets the Israeli government claimed to have terminated on their website turned out not to be any of the civilians involved in the attack. Drones aren't mistaken, they're doing exactly what the program recommends, which is to take out anyone who seems like a threat. Resemblance, once again, is the affective framework through which surveillance and countersurveillance operate in an age of information and control. When an economy of fear surrounds and haunts those who "resemble"

\footnotetext{
${ }^{48}$ Stubblefield, Thomas. Drone Art: The Everywhere War as Medium. The University of California Press, 2020. ${ }^{49}$ Stubblefield, 17.

50 "Gaza: Apparently Unlawful Israeli Strikes Kill At Least 11 Civilians." Human Rights Watch, 28 Oct. 2020, www.hrw.org/news/2020/02/04/gaza-apparently-unlawful-israeli-strikes-kill-least-11-civilians.
} 
the enemy, it allows those in power to justify necropolitical violence and gain hegemonic consensus.

That drones are never seen but instead have an overwhelming sonic presence throughout Home Movies points to the suffocating reality of life under occupation without feeding our appetite for spectacle. Simply reversing the gaze on military drones may give the drones more power by confirming their control and dominance over Palestine's airspace while doing little to challenge the economy of fear and need to contain that sustains this state of exception. In other words, all this does is affirm the anti-terrorism surveillance measures to which many U.S. citizens offer their consent. Additionally, her refusal to show drones while incorporating their sound opens potential windows for resistance through a non-visual medium that works at a more affective level in that these loud droning noises summon a visceral reaction, whether that involves the clenching of teeth or inducing stress. This allows her audience to experience, rather than rely on seeing, the violence of Israeli occupation in Gaza. In the final scene, a night-vision POV wanders through the pitch black night, which is at first drowned out by the noisy buzzing of drones. As the person scrambles through the dark, the sound of chanting in Arabic subsumes the droning. It becomes somewhat evident that these are protest chants, chants which the drone can't hear. Because night vision is grainy and lower in quality, the night will make it all the more difficult for drones to take away their anonymity and autonomy as a group. Anonymity is more valuable than ever in the face of a system that feeds on information as capital and as a way to propel necropolitical violence. Sound and the refusal to highlight suffering individuals in the film actively work against surveillance in withholding information. 


\section{How Not to be Seen}

The title and content of Hito Steyerl's How Not to Be Seen: A Fucking Didactic educational MOV. file pays homage to a Monty Python sketch by the same name in which we gaze at a seemingly empty landscape, until, like a sinister game of whack-a-mole, actors pop up from behind shrubs on cue and are shot dead. ${ }^{51}$ For these sketch subjects, visibility is deadly. According to Steyerl, however, "The situation most people face is that they are visible all the time to different modes of capture," but, "on the other hand, being invisible can be deadly." 52 Like Alsharif and Gary, Steyerl highlights a hands-on interaction with surveillance-related issues of visibility/invisibility, fear, and most specific to Steyerl, informational bodies. The film is broken down into five "lessons," narrated by a computer-generated voice. In Lesson I: "How to make something invisible for a camera," Steyerl deploys her body in various ways to obscure a resolution target--a technology which "measures the visibility of a picture"--that sits in front of a green screen. She places her hand over it "to hide," walks it offscreen "to remove" (Fig. 6), and shields her face with it "to disappear." The narrator then focuses on the resolution target, monotonously stating that "it measures the resolution of the world as a picture," and "resolution determines visibility," thus "whatever is not captured by resolution is invisible.” Lesson II: "How to be invisible in plain sight" details seven ways of doing this, including simply pretending you are not there, and "to scroll, to wipe, to erase, to shrink, to take a picture." Steyerl lathers on green-screen paint in Lesson III: "how to become invisible by becoming a picture," effectively camouflaging herself into the background. Later, bodies acting as "pixels" dance around the screen in front of a digital resolution target (Fig. 7).

\footnotetext{
51 "How Not to be Seen." Monty Python's Flying Circus, created by Monty Python, season 2, episode 11, BBC, 1970.

${ }^{52}$ Fearnley, Jen. "Hito Steyerl: 'Being Invisible Can Be Deadly' - TateShots." Tate, 13 May 2016, www.tate.org.uk/art/artists/hito-steyerl-22462/hito-steyerl-being-invisible-can-be-deadly.
} 


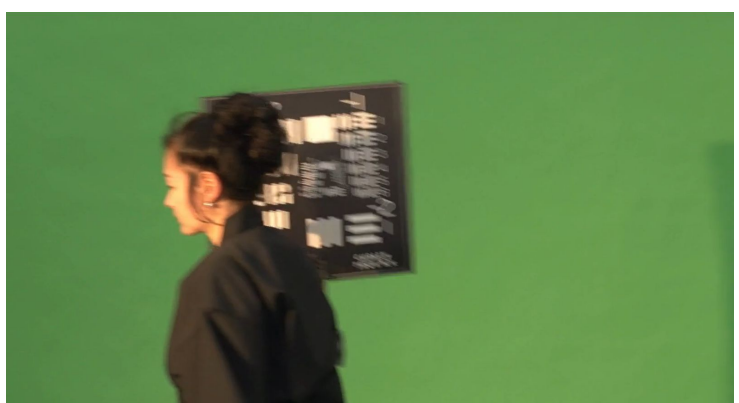

Figure 6

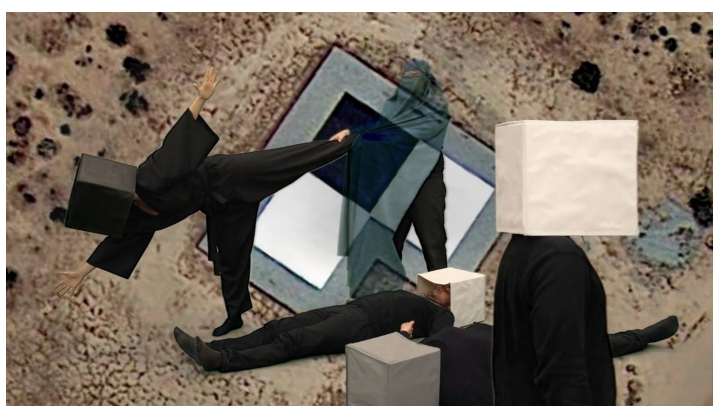

Figure 7

She explores the visibility/invisibility paradox further in her fourth lesson, "How to be invisible by disappearing," by elucidating the various implications of disappearance as an act: one of "fifteen ways of disappearing" she lists includes "living in a gated community," implying that the wealthy disappear themselves as a means to protect social and class hierarchy from the view of the public, as well as to turn their view away from the public. In contrast, "being undocumented or poor" appears later on the list and points to the lived reality of groups who do not have the social or economic capital to be seen, and could more easily be disappeared or deported without attention from the public. So, paradoxically, visibility is also deadly for someone who is criminalized by the state. As is invisibility, on one hand as a force that protects the interests of the powerful, and on the other hand as something that can further erase and harm marginalized groups. Again, this is not equivalent to proposing, as our logic would have it, that visibility is a solution to invisibility or vice versa. After all, her guiding question, "Is there any way for me to not be visible for surveillance?" expresses a relatable desire to evade the surveillant gaze. For those who are closely watched by the state or marked as a threat to national security, this is more so an act of self-preservation than a paranoid afterthought. The visual, in all of its contradictions, is in constant conversation with systems of power, and history, and its own cyclical logic. Resisting visibility as a subject through invisibility can be deadly in addition to liberating, and proves futile. With a series of instructions on how not to be seen while simultaneously living life as an image in a world of images, Steyerl reveals the impossibility of 
hierarchizing visibility and invisibility as tools against state violence, and thus satirizes the insular logic of resisting surveillance through refusal. Instead, the film "educates" us on the power of decentering the subject and thinking of our "world of images" in terms of a control society that operates on the logic of resemblance.

While making oneself invisible might at first sound like Steyerl's "call to action," it must be understood that her tutorial takes into account how governments and corporations weaponize invisibility to support the ongoing exploitation and immobilization of vulnerable populations. The computerized narrator blurs the line between the invisibility of the immaterial and material in saying, "Most important things are invisible... love is invisible, war is invisible, capital is invisible." Just as love only manifests in certain recognizable ways, as in words, and its full scope is invisible and unknown, both the "bigger picture" and the nuances of capital and war remain overwhelmingly invisible due in part to our inability to be in multiple places at the same time: on the battlefield and watching from afar; in the sweatshop and shopping at Target. We only see constructed images of war, and our understanding of war is in many ways reduced to the images we see, which manipulates and alienates experiences and affects that generate and are generated by war. This is not to imply that our misunderstanding is due to false consciousness; there is no "true" nature to love, war, nor capital that we don't see. Rather, "important things," including capital and war are of course made visible in a variety of ways, but their complexity and scope is often hidden as they are reduced to singular concepts. As Steyerl says in her interview with TateShots, invisibility can be deadly, not just for individuals, but as a framework.

Thus, the tutorial explores invisibility as a weapon not only according to visual logic but also its discursive power. In other words, invisibility is not only an absence of the visual but its own performative force. In Monty Python's sketch, characters are killed in cold blood for 
appearing. Steyerl's piece, while emphasizing invisibility's deadliness, intentionally circumvents language around death and instead uses words like "disappeared," "eliminated, liquidated, and then dissimulated." As in Foucault's narrative of overt, spectacle-heavy sovereign power moving toward covert, disciplinary power, discourse around killings and/or disappearances by the surveillance state take on a bureaucratic tone that disguises the necropolitical functions of surveillance. The narration itself is delivered by a robotic, computerized voice void of emotion or personality. By playing up bureaucratic language around death and disappearance, Steyerl mimics the discourse of national security surveillance culture and reveals how this language harnesses the logic of visibility/invisibility in disguising the necropolitical violence of surveillance drones.

Refusing to be visible might in fact make one all the more visible. For one, "such a refusal and opting out are not readily available in the context of the digital milieu"--cited as "“a ubiquitous milieu from which we cannot escape"'--and also, "refusal is itself information." Digital technologies have certainly become essential in late-capitalist control societies, and many have little choice but to engage for the sake of job security, social networking, etc. Even so, those who "opt out" may have, say, a social security number, and will likely need to engage with the technological grid in some form, whether that involves using electricity or being unknowingly surveilled. And then there are those who are criminalized and disappeared for opting out, namely undocumented people. That "refusal is information" holds true for a system in which all choices, whether thought of as refusal or compliance, produce data which is then capitalized on. Suspicion is another issue. Imagine taping over your license plate to avoid surveillance, or wearing a balaclava out on the town before COVID-19 allowed for anonymity

\footnotetext{
${ }^{53}$ Steyerl, Hito. Duty Free Art. Verso, 2017, pp. 94.
} 
via required masks, and somehow not seeming incredibly suspicious to bystanders or authorities. Refusing to be seen means that people pay all the more attention to the absence of what typically "should" not be covered up. This can extend to conversations around Islamophobia and how our national security culture fears the veil for the extent to which it covers the subject, while also making aspects of identity more noticeable. While suppression of veiling has a long history, the debate over banning the veil in places like France is a more recent product of the war on terrorism: "Video footage apparently showing one of the failed July 21, 2005 London bombers wearing a niqab as a disguise has reinforced the notion that the veiling of the face is inherently suspicious and implanted the fear that it may even be a threat to national security." ${ }^{, 54}$ This is not to suggest that the purpose of veiling is to refuse being seen by the state, but it has unintentionally become a sort of refusal following the reshaping of western nationalist ideology to "unite" against (Islamic) "terrorism."

While refusing to be surveilled might produce an ever more surveillable subject, blending into the "digital milieu" and becoming impossible to place as a "thing among other things" allows for escape, not from surveillance, but within surveillance. Some of Steyerl's translucent characters are veiled as the computerized voice-over describes how "invisible people retreat into 3D animations. They hold the vectors of the mesh and keep the picture together--they reemerge as pixels, they merge into a world made of images." The scene is obscured into pixels that fold and form a plane upon which even more veiled people twirl around anonymously. In her own writing, Steyerl finds that camouflaging into a world of images and becoming subject-less defies calls for greater representation and visibility propagated by mass media. But again, rather than opting out completely, Steyerl emphasizes the power of blending and disguising. The veiled

\footnotetext{
54 "Beyond the Burqa." Human Rights Watch, 28 Oct. 2020, www.hrw.org/news/2009/07/02/beyond-burqa.
} 
characters, which multiply after they "reemerge as pixels," are visible yet unknowable as an anonymous group. One veiled subject would perhaps stand out to a drone or surveillance camera, but multiples of the same veiled person confuse the surveillant gaze set on finding the resemblances and differences within a group to harvest as profitable data and valuable national security intel. These veiled "characters," however, are not exactly different characters dressed the same to blend in. It's more correct to say that these veiled objects are reproductions of an image which has no identifiable original source. They are one anti-surveillant object wiped of all metadata necessary to be collected as information for necropolitical control, and may they circulate into infinity. Here we are confronted not with a visual, or anti-visual strategy, but rather with a visualization of how predictive surveillant technologies could be corrupted by abundance, anonymity, and mobility.

\section{Conclusion}

Gary, Alsharif, and Steyerl each bring forth a fresh analysis of everyday surveillance practices congruous with our contemporary moment, in which surveillance has shifted from disciplining through visual strategies to combining visual, informational, and affective modes of control. Their work appropriates surveillance technologies for counter-hegemonic purposes, meaning they utilize and read these technologies against the grain of mainstream perception. The urgency of discussing these works emerges from my observation that a significant amount of popular art about surveillance fails to dig beyond what surveillance looks like in the popular imaginary, i.e. as CCTV cameras and facial recognition technology, and tends to assume a shared, generalized experience of surveillance that in turn erases the ways in which surveillance's impacts are stratified across race, gender, citizenship status, and class. The three 
works I highlight focus on what surveillance does across communities, each focusing on a particular context, yet allowing us to bridge all three into a discussion of how surveillance is in fact a transnational issue. Zeroing in on what surveillance does rather than what it looks like brings to light how affect plays a huge role in how this technology aids white supremacist systems in harming BIPOC communities while it simultaneously expands.

In Gary's piece, the surveillance of blackness in the media, particularly through traumatic spectacles of police brutality, reproduces racist violence by erasing the event's effects on the community surrounding the victim of police brutality (Castile). By covering footage of Castile's lifeless body with process-oriented, handmade film, Gary redirects our attention from a violent spectacle of racist brutality that has been reproduced in the media for decades--from Emmet Till to Rodney King--yet is never "evidence" enough in and of itself to end such brutality. Instead, we're presented with her tactile methods of working through the trauma and fear of feeling unsafe while simultaneously being marked as unsafe in a white supremacist system. From occupation-torn streets of Home Movies, Alsharif paints a different picture of Palestine than the one that the world spends too much time seeing. The film abstracts deadly surveillance technologies, which include drones, honing technology, and night vision in addition to the international media's gaze and reveals how these technologies render all signs of life in Gaza as potential targets, signalling the existence of a slow, ongoing process of Israeli occupation. Having us experience--instead of relying on showing--Gaza makes tangible the everyday necropolitical violence of both military and media surveillance in Palestine. Lastly, Steyerl highlights the paradox of the desire to to avoid the surveillant gaze while at the same time recognizing the deadliness of being invisible--especially for someone who is undocumented, for example, whose invisibility can be easily exploited by an employer, or who can be suddenly 
disappeared. How Not to be Seen thus satirizes the idea of resisting surveillance through this paradoxical logic which relies on visual thinking. Steyerl's use of a robotic, automated narrator, appropriated 3D plans for a resort, and multiplying, unrecognizable veiled figures signals the piece's intention to have us think in terms of the banal informational and digital forms through which technologies of surveillance and control operate and can be dismantled. All three artists make significant contributions to the art and politics of surveillance by opening up new possibilities of understanding how surveillance operates beyond the visual field. It is particularly significant that these artist use moving image work to critique the politics of surveillance and image. My hope is that their critical work will inspire artists and theorists alike to think beyond the imagined limits of their medium while thoughtfully engaging with some of the most urgent questions of our contemporary moment. 


\section{Bibliography}

Ahmed, Sara. "The Affective Politics of Fear," The Cultural Politics of Emotion. Edinburgh UP, 2004, pp. 62-81.

Browne, Simone. Dark Matters: On the Surveillance of Blackness. Duke UP, 2015.

Gary, Ja'Tovia, director. The Giverny Document. 2019.

Gary, Ja’Tovia, director. An Ecstatic Experience. 2015.

“Gaza: Apparently Unlawful Israeli Strikes Kill At Least 11 Civilians.” Human Rights Watch, 28 Oct.2020, hrw.org/news/2020/02/04/gaza-apparently-unlawful-israeli-strikes-kill-least-11-civilians.

Fearnley, Jen. "Hito Steyerl: 'Being Invisible Can Be Deadly' - TateShots." Tate, 13 May 2016, www.tate.org.uk/art/artists/hito-steyerl-22462/hito-steyerl-being-invisible-can-be-deadly.

Foucault, Michel. "Panopticism,” Discipline and Punish. Random House, 1995, pp. 195-228.

Deleuze, Gilles. "Postscript on the Societies of Control." October, vol. 59, 1992, pp. 3-7.

Edelman, Gilad. "A Case Against the Peeping Tom Theory of Privacy.” Wired, Conde Nast, 15 Feb. 2021, www.wired.com/story/against-peeping-tom-theory-of-privacy/.

"Beyond the Burqa." Human Rights Watch, 28 Oct. 2020, www.hrw.org/news/2009/07/02/beyond-burqa.

Bridle, James. New Dark Age: Technology and the End of the Future. Verso, 2019.

Butler, Judith. "Endangered/Endangering," Reading Rodney King, Reading Urban Uprising. Routledge, 1993, pp. 15-22.

Hill, Kashmir. "Wrongfully Accused by an Algorithm." The New York Times, 24 June 2020, www.nytimes.com/2020/06/24/technology/facial-recognition-arrest.html.

Hochberg, Gil. Z. "The Imperative to Witness and the Menace of the Global Gaze," Visual Occupations: Violence and Visibility in a Conflict Zone. Duke UP, 2015, pp. 115-137.

Hole, Kristin. "Negotiating the Aporias of Palestinian Identity through Experimental Moving Image Work" (Under Review).

"How Not to be Seen." Monty Python's Flying Circus, created by Monty Python, season 2, episode 11, BBC, 1970. 
Human Rights Clinic at Columbia Law School. "The Civilian Impact of Drones: Unexamined Costs, Unanswered Questions." Center for Civilians in Conflict, 2012, civiliansinconflict.org/publications/research/civilian-impact-drones-unexamined-costs-unans wered-questions/.

Massumi, Brian. "The Future Birth of the Affective Fact," The Affect Theory Reader, 2010, pp. 52-67.

Mbembé, Achille. "Necropolitics” Public Culture, vol. 15 no. 1, 2003, pp. 11-40.

Nauman, Bruce. Video Surveillance Piece: Public Room, Private Room. 1969.

Puar, Jasbir. Terrorist Assemblages: Homonationalism in Queer Times. Duke UP, 2007.

Steyerl, Hito. Duty Free Art. Verso, 2017.

Stubblefield, Thomas. Drone Art: The Everywhere War as Medium. The University of California Press, 2020.

Weiwei, Ai. Surveillance Camera and Plinth. 2015, Mary Boone Gallery, New York. 